ks. Paweł Prüfer

Akademia im. Jakuba z Paradyża w Gorzowie Wielkopolskim

Bernadeta Piszczygłowa

Uniwersytet Ekonomiczny w Poznaniu

\title{
PRACA I BEZROBOCIE - UWARUNKOWANIA PSYCHOSPOŁECZNE. ANALIZA ZJAWISK W LOKALNEJ ODSŁONIE
}

\author{
Unemployment and work - psychosocial conditions. \\ Analysis of the phenomenon in the localised form
}

\begin{abstract}
Streszczenie
Praca jako aktywność ludzka jest jednym z podstawowych czynników kształtujących stabilność społeczeństwa oraz życie jednostki, bezrobocie zaś stanowi element destabilizacji i ryzyka. W artykule zaprezentowano najpierw teoretyczną analizę obu zjawisk, a następnie wskazano na ich specyficzne fluktuacje w Gorzowie Wielkopolskim, opierając się na danych udostępnionych przez powiatowy urząd pracy z lat 2015 oraz 2017-2019.
\end{abstract}

Słowa kluczowe: praca, bezrobocie, Gorzów Wielkopolski

\begin{abstract}
Work as a human activity is one of the fundamental factors shaping the stability of society and an individual life. Unemployment as a phenomenon closely related to work is an element of destabilization and risk. Firstly, this article presents a theoretical analysis of both phenomena, and then indicates its specific fluctuations in a specific area of the country. This analysis is based on data provided by the Poviat Labor Office in Gorzów Wielkopolski.
\end{abstract}

Keywords: job, unemployment, Gorzów Wielkopolski

\section{Wprowadzenie}

Istnieją zjawiska społeczne, które niezmiennie, niezależnie od upływu czasu, zmian kulturowych oraz fluktuacji społeczno-gospodarczych, stanowią przedmiot refleksji i analiz naukowych. Georg Simmel w eseju Podziat pracy jako przyczyna rozejścia się kultury subiektywnej i kultury obiektywnej wskazywał na oddzielenie osoby podejmującej pracę od tego, co stanowi o jej złożonej strukturze (2008: 130). Można stwierdzić, w sensie dosłownym, że istnieje zjawisko rozejścia się pracy oraz człowieka, zarówno jako homo faber, jak i animal laborans. Dzieje się tak wówczas, gdy owo rozejście jest wywoływane deficytami związanymi z ofertą pracy, ale także wtedy, kiedy sytuacja społeczna sprawia, że praca staje się mało atrakcyjna. Praca jest jednym z wielu komponentów rynkowych. To właśnie rynek w decydującej mierze kształtuje strategię oferowania pracy, jej uelastyczniania czy różnicowania.

W artykule przedstawiono analizę teoretyczno-empiryczną dotyczącą zjawiska pracy oraz powiązanego z nim bezrobocia, wskazując na czynniki, które wywołują w tym obszarze różnorodne fluktuacje i reperkusje. Zazwyczaj eksploracji poddaje się zjawisko, które ma wyraziste kształty i niejako narzuca się badaczowi z racji jego silnego oddziaływania społecznego oraz gdy przedkłada się obserwatorowi z racji swojego szerokiego 
zasięgu. W ostatnim czasie odnotowuje się w Polsce znaczący spadek skali bezrobocia, lecz właśnie ów fakt ma swoje specyficzne konsekwencje, a zjawisko samo w sobie jest determinowane specyficzną logiką. Dotyczy to także zachodniej części kraju, w tym regionu gorzowskiego. Uzyskane dane z Powiatowego Urzędu Pracy (PUP) w Gorzowie Wielkopolskim stanowią interesujący materiał do naukowej analizy zjawiska oraz oceny sytuacji społecznej, psychologicznej i gospodarczej.

\section{Rynek pracy}

Rynek pracy jest jednym z rodzajów rynków. Obok towarowego, pieniężnego i kapitałowego stanowi on istotny obszar działania gospodarczego. Zgodnie z jedną z prostszych definicji to rodzaj rynku, na którym przedmiotem wymiany pomiędzy kupującym a sprzedającym jest praca, gdzie kupującym jest oferujący zatrudnienie pracodawca, a sprzedającym - pracownik otrzymujący za swoją pracę określone wynagrodzenie (Kobiałka 2012: 7). Można posłużyć się pewną klasyfikacją dotyczącą składników rynku pracy:

- pracownicy (workers), którzy podejmują zatrudnienie dobrowolnie lub z niego rezygnują;

- pracodawcy (employers), którzy samodzielnie podejmują decyzje o zatrudnianiu lub zwalnianiu pracowników;

- zawody, zajęcia (jobs), które składają się na podział pracy według firm i zróżnicowanie stanowisk wewnątrz firm;

- zatrudnienie (hiring) - transakcje, w których pracownicy otrzymują do wykonania pracę w zamian za określone wynagrodzenie, zrzucając jednocześnie część kontroli nad swoją pracą na pracodawców;

- sieci (networks), czyli kanały komunikacji łączące potencjalnych kandydatów do pracy w różnych firmach z pracodawcami, którzy podejmują decyzje o zatrudnieniu;

- kontrakty - umowy (contracts), stanowiące formalne porozumienia lub uzgodnione domyślnie normy odnoszące się do zadań do wykonania, nakładów pracy, warunków pracy oraz wynagrodzenia (Giermanowska 2013: 21).

Interesująco przedstawia się syntetyczna analiza rynku pracy w opracowaniu Romana Przybyszewskiego: „Elementami rynku pracy są: kapitał ludzki i jego kwalifikacje, grupy pracowników zatrudnione w poszczególnych sektorach gospodarki narodowej oraz wielkość i struktura bezrobocia. Elementami kapitału intelektualnego przedsiębiorstwa są: wiedza, posiadane doświadczenie, stosowana technologia organizacyjna, stosunki z klientami, jak również umiejętności zawodowe pracowników” (2007: 137). Do podstawowych elementów rynku pracy należą: popyt na pracę, podaż pracy oraz, ściśle z nimi związane, wynagrodzenie za pracę (Buchwald 2009: 11). Popyt na pracę zgłaszają przedsiębiorstwa, kierując się maksymalizacją zysku, ponieważ to poziom produkcji opłacalnej dyktuje, przy danych warunkach techniczno-ekonomicznych, wielkość zatrudnienia (Próchnicki 2008: 310). Podaż pracy natomiast to zasoby pracy dostępne na rynku, czyli ilość pracy generowana przez pracowników gotowych podjąć pracę przy określonych stawkach płac. Podaż pracy zależy od czynników demograficznych, wysokości oferowanego za pracę wynagrodzenia oraz preferencji pracowników dotyczących czasu wolnego i pracy, natomiast popyt na pracę, czyli liczba oferowanych miejsc pracy, od zapotrzebowania na towary i usługi, kosztów pracy i wydajności pracy. Podaż pracy zależy również od liczby osób w wieku produkcyjnym, które rzeczywiście poszukują pracy, chociaż coraz częściej osoby będące w wieku emerytalnym nie rezygnują z zatrudnienia (Kobiałka 2012: 7).

Wpływ na sytuację na rynku pracy mają następujące czynniki:

1. Czynniki polityczne. Nic nie dzieje się na rynku pracy bez udziału polityki, polityków, reprezentacji pracodawców oraz pracowników, organizacji międzynarodowych. Na rynek pracy wywierane są różnorodne naciski, od etapu przygotowania regulacji rynkowych (etap legislacyjny, lobbing) do wprowadzenia poszczególnych rozwiązań w życie, a także poprzez decyzje polityczne, jak np. prywatyzacja zakładów pracy.

2. Czynniki ekonomiczne. Przede wszystkim globalizacja, gdyż globalnie rynki pracy prawie wszędzie się kurczą, ale stwarza się warunki do przemieszczania się ludzi w celu znalezienia pracy. Nie jest to jednak proste, gdyż zawsze przeważają interesy danego kraju. Problemem stają się również fuzje 
i przejęcia, powodujące wzrost bezrobocia, a także kryzysy ekonomiczne rozlewające się ostatnio na cały niemal świat i mające długotrwały charakter.

3. Czynniki technologiczne. Wynikają z nowych rozwiązań technicznych, wdrożeń innowacyjnych, przede wszystkim z obszaru IT. Istotne są tutaj także nowe sposoby zarządzania, w tym programy komputerowe wspomagające lub nawet zastępujące pracę ludzi.

4. Czynniki społeczne. Przede wszystkim: starzenie się społeczeństw, większa mobilność pracowników, większa podaż kobiet na rynku pracy, elastyczny czas pracy oczekiwany przez pracowników i pracodawców, dążenie pracowników do stałej pracy i zabezpieczeń społecznych, a także bezrobocie (Szaban 2013: 34-35).

Praca stanowi przedmiot rynku pracy. Często definiowano ją jako „podaż zasobów ludzkich, zarówno fizycznych, jak i umysłowych, które można włączyć w proces produkcji towarów i usług” (Whitehead 2001: 248). Bezrobocie jest stanem przeciwstawnym pracy (Kwiatkowska 2011: 112). W przypadku gdy popyt na pracę zrówna się z podażą pracy, powstaje stan równowagi na rynku pracy. Gdy podaż pracy jest większa niż popyt na pracę, pojawia się bezrobocie: pewna część ludzi zdolnych do pracy, poszukujących pracy i akceptujących istniejący poziom wynagrodzenia pozostaje bez pracy (Kobiałka 2012: 7).

\section{Bezrobocie}

Zjawisko bezrobocia pojawiło się w czasach rewolucji przemysłowej w Anglii na przełomie XVIII i XIX w. (Kwiatkowska 2011: 67). Również termin „bezrobocie” w obecnym znaczeniu pojawił się pod koniec XIX w., gdyż wcześniej utożsamiany był z „mimowolną bezczynnością” czy „chęcią zatrudnienia” (Kwiatkowska 2011: 113-114). „Bezrobociem nazywa się liczbę niepracujących ludzi dorosłych, którzy są zdolni do pracy i poszukują jej. W różnych krajach ustawodawstwo niejednakowo precyzuje wymagania dotyczące wieku, czasu poszukiwania pracy, obowiązku rejestracji, itp., więc nie zawsze jest wielkością porównywalną w skali międzynarodowej” (Beksiak 2001: 172).

Spoglądając retrospektywnie w kontekst polski, warto zauważyć, że państwo socjalistyczne jako pracodawca łączyło w swych działaniach elementy polityczne i socjalne, mając na celu realizację takich społecznych zamierzeń, jak pełne zatrudnienie, wprowadzenie ubezpieczeń społecznych na starość, szczególne warunki ochrony pracy kobiet oraz młodocianych, bezpłatna opieka zdrowotna itd. (Skrzypiński 2001: 63-64). Problem bezrobocia ujawnił się wraz z przekształceniami gospodarki z planowanej na rynkową, gdy nagła zmiana systemowa w 1989 r., bez przygotowania firm do niej, spowodowała masowe zwolnienia (Kwiatkowska 2011: 67). W Polsce w latach 90. przemożny wpływ na stosunki pracy wywarły problem bezrobocia, masowych zwolnień oraz kłopoty z utrzymaniem zatrudnienia (Kozek 2003: 52). W okresie tym powstało wiele firm, głównie małych, często rodzinnych, w których zatrudniało się na czarno i w niestandardowych formach zatrudnienia. Jednym z celów transformacji systemu gospodarczego przeprowadzonej przez rząd Tadeusza Mazowieckiego, której podstawę stanowił plan Balcerowicza, było wprowadzenie ustawy o zatrudnieniu unieważniającej ustawę o osobach uchylających się od pracy oraz zmieniającej zasady działania biur pośrednictwa pracy, dostosowując je do nowego rynku pracy funkcjonującego w warunkach bezrobocia, oraz ustawy o grupowych zwolnieniach z pracy, która stworzyła przepisy prawne chroniące zwalnianych z pracy (Skrzypiński 2001: 78-79).

W Polsce transformacja systemowa oraz akcesja do Unii Europejskiej wywołały zmiany na dwóch poziomach: powstały nowe formalne instytucje, ale także zmieniły się instytucje w najszerszym socjologicznym rozumieniu, zmieniło się działanie jednostek, kategorii, grup społecznych, powstały nowe wzory zachowań, myślenia i wartościowania, ludzie wypracowali nowe strategie przystosowawcze oraz nowe sposoby radzenia sobie z rzeczywistością (Woźniak 2013: 58).

Rozmiary bezrobocia określane są przez trzy czynniki: współczynnik aktywności zawodowej, liczbę ludności w wieku produkcyjnym oraz wielkość zatrudnienia (Milewski 1997: 245). Bezrobocie może być spowodowane:

- likwidacją niektórych gałęzi przemysłu,

- zmniejszeniem popytu na konkretne dobra czy usługi, 
- ograniczaniem produkcji,

- przeniesieniem zakładu do innego rejonu,

- zmianamiw technologii,

- wysokimi obciążeniami fiskalnymi,

- brakiem odpowiednich proporcji między wysokością płac a świadczeniami dla bezrobotnych (Kobiałka 2012: 7).

W zależności od uwzględnianych czynników bezrobocie dzieli się na różne rodzaje. Przykłady typologii przedstawiają tabele 1 i 2.

Tabela 1. Rodzaje bezrobocia - typologia I

\begin{tabular}{|l|l|}
\hline Rodzaj bezrobocia & \multicolumn{1}{c|}{ Charakterystyka } \\
\hline Frykcyjne & $\begin{array}{l}\text { Wynika z braku dostatecznej informacji na temat istniejących wolnych miejsc pracy i osób } \\
\text { szukających pracy. }\end{array}$ \\
\hline Strukturalne & $\begin{array}{l}\text { Jest to niedopasowanie kwalifikacji i umiejętności lub miejsca zamieszkania osób bezrobot- } \\
\text { nych do potrzeb pracodawców. }\end{array}$ \\
\hline Sezonowe & $\begin{array}{l}\text { Spowodowane sezonowością produkcji (na ogół uzależnionej od klimatu). Dotyczy takich } \\
\text { gałęzi gospodarki, jak: rolnictwo, budownictwo czy usługi turystyczne. }\end{array}$ \\
\hline Koniunkturalne & $\begin{array}{l}\text { Wiąże się z cyklicznością rozwoju gospodarczego. Pojawia się w fazie recesji, w okresie roz- } \\
\text { woju może ulec częściowej lub całkowitej likwidacji. }\end{array}$ \\
\hline Dobrowolne & $\begin{array}{l}\text { Dotyczy sytuacji, w której osoba bezrobotna nie podejmuje decyzji o podjęciu pracy po } \\
\text { porównaniu kosztów i korzyści związanych z zatrudnieniem. }\end{array}$ \\
\hline Przymusowe & $\begin{array}{l}\text { Powstaje, gdy przy danym poziomie płacy realnej osoby bezrobotne nie są w stanie znaleźć } \\
\text { pracy, mimo gotowości do jej podjęcia (gdy popyt na pracę jest mniejszy niż podaż pracy). }\end{array}$ \\
\hline
\end{tabular}

Źródło: Kobiałka 2012: 7-8.

Tabela 2. Rodzaje bezrobocia - typologia II

\begin{tabular}{|l|l|}
\hline Rodzaj bezrobocia & \multicolumn{1}{c|}{ Charakterystyka } \\
\hline Równowagi & $\begin{array}{l}\text { Charakteryzuje się tym, że nie znika nawet w warunkach wzrostu gospodar- } \\
\text { czego i mieści się w stanie pełnego zatrudnienia. Zalicza się do niego bezrobocie } \\
\text { strukturalne. }\end{array}$ \\
\hline Nierównowagi & $\begin{array}{l}\text { Stanowi pozostałą część bezrobocia całkowitego (tj. poza bezrobociem równowagi). } \\
\text { Jego główne źródła tkwią w zmianach sytuacji (koniunktury) gospodarczej. Bywa też } \\
\text { określane mianem bezrobocia cyklicznego. }\end{array}$ \\
\hline Instytucjonalne & $\begin{array}{l}\text { Obejmuje zwłaszcza takie zachowania pracodawców, które wiążą się z brakiem ich } \\
\text { zainteresowania w zatrudnianiu bezrobotnych. }\end{array}$ \\
\hline
\end{tabular}

Źródło: Jarmołowicz, Woźniak 2006: 113-114.

Zjawisko bezrobocia może być typologizowane także w odniesieniu do ewidencji statystycznej:

- jawne (rejestrowane), którego wysokość ustalana jest na podstawie danych uzyskanych z urzędów pracy; dotyczy przede wszystkim ośrodków miejskich;

- ukryte - dotyczy osób, które z różnych przyczyn, pomimo braku pracy, nie rejestrują się jako osoby bezrobotne, przez co nie są uwzględniane w skali bezrobocia (Kwiatkowska 2011: 68).

W zależności od czasu pozostawania osób bezrobotnych bez pracy bezrobocie dzieli się na:

- krótkookresowe - do 3 miesięcy,

- średniookresowe - od 4 do 6 miesięcy,

- długookresowe - od 7 do 12 miesięcy, 
- długotrwałe - powyżej 1 roku,

- chroniczne - powyżej 2 lat (Kobiałka 2012: 8).

Jak potwierdzają badacze zjawiska, zwłaszcza socjologowie, bezrobocie wywołuje negatywne skutki społeczne i ekonomiczne, które mają znaczenie zarówno dla samych osób bezrobotnych, jak i dla gospodarki jako całości, gdyż nie tylko powoduje ono pogorszenie poziomu życia osób bezrobotnych, frustrację, wzrost niezadowolenia oraz rozwój szeregu niekorzystnych zjawisk społecznych, ale również na płaszczyźnie makroekonomicznej - niepełne wykorzystanie zasobów siły roboczej i w związku z tym niższą produkcję (Milewski 1999: 532).

Jednym z rodzajów polityki gospodarczej państwa jest polityka wobec rynku pracy, przyjmująca za podstawowy cel pełne zatrudnienie, czyli taki stan zatrudnienia, który wiąże się z mniej lub bardziej akceptowaną (naturalną) stopą bezrobocia, a więc i bezrobocia równowagi. Państwo, wyznaczając sobie za cel pełne zatrudnienie i uznając potrzebę ingerencji w mechanizm rynku pracy, wykorzystuje różne rodzaje polityki w dziedzinie wzrostu zatrudnienia i ograniczania bezrobocia:

- oddziaływanie na popyt na pracę oraz na podaż pracy i niedopasowania strukturalne na rynku pracy,

- oddziaływanie na bezrobocie równowagi i bezrobocie nierównowagi,

- metody polityki ekonomicznej w układzie instrumentalnym,

- metody polityki ekonomicznej w układzie segmentowym,

- politykę makro- i mikroekonomiczną,

- politykę zatrudnienia i politykę rynku pracy,

- politykę popytową i podażową,

- politykę ekonomiczną i politykę deregulacji rynku pracy.

Wśród wymienionych wyżej typów i rodzajów polityki państwa w dziedzinie zwiększania zatrudnienia i ograniczania bezrobocia ważne miejsce zajmuje polityka oddziaływania na bezrobocie równowagi i nierównowagi (Jarmołowicz, Woźniak 2006: 115).

Zjawisko możliwości powstawania bezrobocia jest interesującym przedmiotem badawczym dla makroekonomii. Związane są z tym zagadnieniem dwa problemy: pierwszy dotyczy wyznaczników średniego bezrobocia w dłuższych okresach, a m.in. kwestii tego, czy to bezrobocie reprezentuje autentyczny fakt nieopróżniania się rynków, a jeśli tak, to co jest tego przyczyną i jakie są tego konsekwencje; drugi dotyczy cyklicznego kształtowania się rynku siły roboczej (Romer 2000: 476).

Ustawa z dnia 20 kwietnia 2004 r. o promocji zatrudnienia i instytucjach rynku pracy (Dz.U. 2018 poz. 1265) określa zadania państwa w zakresie promocji zatrudnienia, łagodzenia skutków bezrobocia oraz aktywizacji zawodowej, które są realizowane przez instytucje rynku pracy działające w celu: pełnego i produktywnego zatrudnienia, rozwoju zasobów ludzkich, osiągnięcia wysokiej jakości pracy, wzmacniania integracji oraz solidarności społecznej, zwiększania mobilności na rynku pracy. Powiatowe urzędy pracy rejestrują bezrobotnych i poszukujących pracy oraz prowadzą rejestr tych osób i niezwłocznie po rejestracji ustalają dla bezrobotnego profil pomocy, oznaczający właściwy ze względu na potrzeby bezrobotnego zakres form pomocy określonych w ustawie, tj.:

- pośrednictwo pracy, a także w uzasadnionych przypadkach poradnictwo zawodowe lub określone w ustawie formy pomocy;

- usługi i instrumenty rynku pracy, działania aktywizacyjne zlecone przez urząd pracy oraz inne formy pomocy z wyłączeniem Programu Aktywizacja i Integracja;

- Program Aktywizacja i Integracja, działania aktywizacyjne zlecone przez urząd pracy, programy specjalne, skierowanie do zatrudnienia wspieranego u pracodawcy lub podjęcia pracy w spółdzielni socjalnej zakładanej przez osoby prawne oraz w uzasadnionych przypadkach poradnictwo zawodowe.

\section{Rynek pracy i bezrobocie w Gorzowie Wielkopolskim}

Obecny rynek pracy jest rynkiem pracownika. W 2018 r. PUP w Gorzowie Wielkopolskim odnotował w powiecie grodzkim i ziemskim - spadek bezrobocia o 36,15\%. W 2018 r. zarejestrowanych (napływ) było 7688 osób, a w 2015 r. - 12 040. Odnotowano również nieco większy spadek liczby osób wyrejestrowanych 
(odpływ) - o 38,33\%. W 2018 r. wyrejestrowano 7083 osoby, w tym z tytułu podjęcia pracy - 3548, natomiast w 2015 r. wyrejestrowano 12653 osoby, w tym z tytułu podjęcia pracy - 5587.

Tabela 3. Stan bezrobocia

\begin{tabular}{|l|c|c|c|c|}
\hline Bezrobotni & $\mathbf{2 0 1 5}$ & $\mathbf{2 0 1 8}$ & Różnica & $\begin{array}{c}\text { Różnica } \\
\text { w \% }\end{array}$ \\
\hline Zarejestrowani (napływ) & 12040 & 7688 & -4352 & $-36,15$ \\
\hline $\begin{array}{l}\text { Wyrejestrowani (odpływ) } \\
\text { w tym z powodu: }\end{array}$ & 12653 & 7803 & -4850 & $-38,33$ \\
\hline $\begin{array}{l}\text { podjęcia pracy } \\
\text { niepotwierdzenia gotowości do podjęcia } \\
\text { pracy }\end{array}$ & 5587 & 3548 & -2039 & $-36,50$ \\
\hline $\begin{array}{l}\text { dobrowolnej rezygnacji ze statusu } \\
\text { bezrobotnego }\end{array}$ & 978 & 845 & -2120 & $-53,21$ \\
\hline $\begin{array}{l}\text { odmowy bez uzasadnionej przyczyny } \\
\text { przyjęcia propozycji odpowiedniej pracy } \\
\text { lub innej formy pomocy }\end{array}$ & 328 & 300 & -28 & $-13,60$ \\
\hline
\end{tabular}

Źródło: opracowanie własne na podstawie danych PUP w Gorzowie Wielkopolskim..

Wśród osób bezrobotnych na koniec 2018 r. 872 osoby nie miały kwalifikacji zawodowych, natomiast na koniec 2015 r. - 1464 osoby (spadek o 40,44\%). Spadek (o 29,28\%) odnotowano również w kategorii osób długotrwale bezrobotnych. Na koniec 2018 r. w tej kategorii zarejestrowano 843 osoby, natomiast na koniec 2015 r. - 1192.

Tabela 4. Wybrane kategorie bezrobotnych (wg stanu na 31 grudnia danego roku)

\begin{tabular}{|l|c|c|c|c|}
\hline Bezrobotni & $\mathbf{2 0 1 5}$ & $\mathbf{2 0 1 8}$ & Różnica & Różnica w \% \\
\hline Bez kwalifikacji zawodowych & 1464 & 872 & -592 & $-40,44$ \\
\hline Długotrwale bezrobotni & 1192 & 843 & -349 & $-29,28$ \\
\hline
\end{tabular}

Źródło: jak przy tabeli 3.

Pracownicy powiatowego urzędu pracy ustalają profil pomocy dla każdej osoby bezrobotnej na podstawie wywiadu przeprowadzonego z tą osobą, wspieranego systemem teleinformatycznym udostępnianym przez ministra właściwego do spraw pracy. Osoby bezrobotne mają obowiązek zgłaszania się do właściwego powiatowego urzędu pracy w wyznaczonym przez urząd terminie w celu przyjęcia propozycji odpowiedniej pracy lub innej formy pomocy proponowanej przez urząd lub w innym celu wynikającym z ustawy i określonym przez urząd pracy, w tym potwierdzenia gotowości do podjęcia pracy. W celu wspomagania osób bezrobotnych i poszukujących pracy w rozwiązywaniu specyficznych problemów zawodowych doradcy zawodowi świadczą usługi poradnictwa zawodowego w formie rozmów wstępnych, udzielają także porad indywidualnych i grupowych oraz informacji zawodowych indywidualnych i grupowych.

Tabela 5. Poradnictwo zawodowe

\begin{tabular}{|l|r|r|r|c|}
\hline Formy poradnictwa & $\mathbf{2 0 1 5}$ & $\mathbf{2 0 1 8}$ & Różnica & Różnica w \% \\
\hline Porady indywidualne & 2746 & 2069 & 677 & $-24,65$ \\
\hline Porady grupowe (osoby) & 186 & 136 & 50 & $-26,88$ \\
\hline Porady grupowe (grupy) & 26 & 17 & 9 & $-34,62$ \\
\hline Informacja zawodowa grupowa (osoby) & 59 & 100 & 41 & 69,49 \\
\hline Informacja zawodowa grupowa (grupy) & 6 & 13 & 7 & 116,67 \\
\hline
\end{tabular}

Źródło: jak przy tabeli 3. 
Liczba porad indywidualnych i grupowych w 2018 r. w stosunku do 2015 r. zmniejszyła się odpowiednio o $24,65 \%$ oraz $26,88 \%$ w przypadku osób i $34,62 \%$ w przypadku grup, natomiast informacja zawodowa grupowa była udzielana częściej o 69,49\% w przypadku osób i 116,67\% w przypadku grup.

W ramach poradnictwa zawodowego grupowego PUP w Gorzowie Wielkopolskim zrealizował wiele różnorodnych zajęć (tabela 6).

Tabela 6. Tematyka zajęć zrealizowanych w ramach poradnictwa grupowego

\begin{tabular}{|c|c|c|}
\hline Lp. & Temat & Cel zajęć \\
\hline 1. & $\begin{array}{l}\text { „Bliżej pracy” - kształtowanie postawy } \\
\text { aktywnej u osób bezrobotnych }\end{array}$ & $\begin{array}{l}\text { Aktywizacja zawodowa, zwiększenie wiary we własne siły, pozna- } \\
\text { nie lokalnego rynku pracy. }\end{array}$ \\
\hline 2. & Kurs inspiracji & $\begin{array}{l}\text { Budowanie motywacji oraz inspirowanie uczestników do aktyw- } \\
\text { ności w poszukiwaniu zatrudnienia. }\end{array}$ \\
\hline 3. & $\begin{array}{l}\text { Autoprezentacja - dostarczenie wiedzy } \\
\text { i umiejętności budowania własnego wize- } \\
\text { runku zawodowego }\end{array}$ & $\begin{array}{l}\text { Przygotowanie do rozmowy kwalifikacyjnej i prezentacja własnej } \\
\text { osoby. }\end{array}$ \\
\hline 4. & $\begin{array}{l}\text { Komputer jako narzędzie poszukiwania } \\
\text { pracy }\end{array}$ & $\begin{array}{l}\text { Nabycie podstawowych umiejętności praktycznego wykorzysta- } \\
\text { nia nowoczesnych technik informatycznych pod kątem poszuki- } \\
\text { wania zatrudnienia. }\end{array}$ \\
\hline 5. & $\begin{array}{l}\text { Marketing własnej osoby - trudna sztuka } \\
\text { poznania siebie }\end{array}$ & $\begin{array}{l}\text { Budowanie motywacji oraz inspirowanie uczestników do } \\
\text { aktywności w poszukiwaniu zatrudnienia. }\end{array}$ \\
\hline 6. & $\begin{array}{l}\text { Szkolenie z zakresu umiejętności poszuki- } \\
\text { wania pracy }\end{array}$ & Przygotowanie osób do powrotu na lokalny rynek pracy. \\
\hline 7. & $\begin{array}{l}\text { Komunikacja interpersonalna w rozmo- } \\
\text { wie z pracodawcą }\end{array}$ & Akty \\
\hline 8. & Poczucie własnej wartości & $\begin{array}{l}\text { Aktywizacja zawodowa, zwiększenie wiary we własne siły oraz } \\
\text { motywacji do poszukiwania pracy. }\end{array}$ \\
\hline 9. & $\begin{array}{l}\text { Przygotowanie do rozmowy } \\
\text { kwalifikacyjnej }\end{array}$ & $\begin{array}{l}\text { Nabycie umiejętności rozpoznawania swoich cech charakteru, } \\
\text { samooceny i wypowiadania się na swój temat oraz zwiększenie } \\
\text { wiary w siebie. }\end{array}$ \\
\hline 10. & Artreterapia sposobem na stres & Aktywizacja zawodowa. \\
\hline 11. & Dokumenty aplikacyjne w praktyce & Aktywizacja zawodowa. \\
\hline 12. & $\begin{array}{l}\text { Mocne i słabe strony w kontakcie } \\
\text { z pracodawcą }\end{array}$ & $\begin{array}{l}\text { Aktywizacja zawodowa - przygotowanie do poszukiwania } \\
\text { zatrudnienia. }\end{array}$ \\
\hline 13. & $\begin{array}{l}\text { „Wygraj siebie” - jak dobrze zaprezento- } \\
\text { wać się pracodawcy }\end{array}$ & $\begin{array}{l}\text { Nabycie umiejętności rozpoznawania swoich cech charakteru, } \\
\text { samooceny i wypowiadania się na swój temat oraz podniesienie } \\
\text { wiary w siebie. }\end{array}$ \\
\hline
\end{tabular}

Źródło: jak przy tabeli 3.

Usługi pośrednictwa pracy w 2015 r. objęły 29705 osób. W ramach tych usług doradcy klienta, m.in. pośrednicy pracy, przedstawiali dostępne oferty pracy. Wydano 10914 skierowań do pracy $(36,74 \%$ liczby usług w 2015 r.). W 2018 r. z usług pośrednictwa pracy skorzystało 16546 osób, czyli o 44,3\% mniej w stosunku do 2015 r. Wydano 6876 skierowań do pracy (41,56\% liczby usług w 2018 r.), czyli o 37\% mniej w stosunku do 2015 r. Wśród ofert pracy znajdowały się oferty pracy subsydiowanej oraz niesubsydiowanej. 
Tabela 7. Oferty pracy zgłoszone przez pracodawców

\begin{tabular}{|l|c|c|c|c|}
\hline Oferty pracy & $\mathbf{2 0 1 5}$ & $\mathbf{2 0 1 8}$ & Różnica & $\begin{array}{c}\text { Różnica } \\
\text { w \% }\end{array}$ \\
\hline Razem & $\mathbf{7 3 1 7}$ & $\mathbf{1 5 1 1 3}$ & $\mathbf{7 7 9 6}$ & $\mathbf{2 0 6 , 5 4}$ \\
\hline w tym: niesubsydiowanej & 5834 & 14217 & 8383 & 243,69 \\
\hline \multicolumn{1}{|c|}{ subsydiowanej } & 1483 & 896 & -587 & $-39,58$ \\
\hline
\end{tabular}

Źródło: jak przy tablicy 3.

Jedną z metod poszukiwania pracowników jest składanie w urzędzie pracy wniosków pracodawców o skierowanie osób bezrobotnych na wskazane stanowiska pracy. Od stycznia do maja 2019 r. do PUP w Gorzowie Wielkopolskim wpłynęło 145 ofert na 424 miejsca pracy, w tym 24 staże. Jak przedstawiono w tabeli 8, pracodawcy oferują bardzo zróżnicowane wynagrodzenia na różnych stanowiskach pracy. Trudno znaleźć zależność wysokości oferowanego wynagrodzenia od kwalifikacji. Dla 180 stanowisk, tj. 42,45\% wszystkich miejsc pracy, zaoferowano minimalne wynagrodzenie (2250,00 zł brutto). W tej grupie znalazły się zarówno stanowiska niewymagające w zasadzie żadnych kwalifikacji (robotnik gospodarczy), jak i stanowiska, na których prócz odpowiednich kwalifikacji wymagane są również różnego rodzaju specjalistyczne uprawnienia (np. termoizolator, operator maszyn do wodorowania). Proponowane wynagrodzenie od 3000,00 zł dotyczy jedynie 101 stanowisk, tj. 23,82\%.

Tabela 8. Rodzaje ofert pracy zgłoszonych przez pracodawców w 2019 r. (wg stanu na 17 maja)

\begin{tabular}{|c|c|c|}
\hline Stanowiska & $\begin{array}{l}\text { Wynagrodzenie } \\
\text { brutto od (w zl) }\end{array}$ & $\begin{array}{c}\text { Liczba } \\
\text { stanowisk } \\
\text { pracy } \\
\end{array}$ \\
\hline $\begin{array}{l}\text { Termoizolator, pomoc stolarza, pomocnik piekarza, magazynier, pracownik } \\
\text { myjni samochodowej, operator maszyny do wodorowania, stolarz budowlany, } \\
\text { robotnik gospodarczy, mechanik samochodowy, konserwator, pracownik bu- } \\
\text { dowlany, szpachlarz malarz, pracownik restauracji, goniec, młodszy asystent, } \\
\text { naprawiacz, kontroler materiałowy, introligator, przedstawiciel handlowy, } \\
\text { tokarz }\end{array}$ & 2250 & 180 \\
\hline $\begin{array}{l}\text { Kierowca zaopatrzeniowiec, pracownik gospodarczy, kierowca autobusu, } \\
\text { szwaczka }\end{array}$ & 2300 & 57 \\
\hline Sprzątaczka, pracownik gospodarczy, konserwator, & 2400 & 18 \\
\hline Pracownik magazynowy, magazynier - sprzedawca, nauczyciel & 2500 & 21 \\
\hline Fizjoterapeuta & 2600 & 6 \\
\hline $\begin{array}{l}\text { Nauczyciel przedmiotów informatycznych, nauczyciel przedmiotów elek- } \\
\text { trycznych, nauczyciel przedmiotów mechatronicznych, nauczyciel przed- } \\
\text { miotów elektronicznych, nauczyciel przedmiotów teleinformatycznych, } \\
\text { nauczyciel programista, nauczyciel automatyki }\end{array}$ & 2611 & 7 \\
\hline Kucharka & 2700 & 1 \\
\hline $\begin{array}{l}\text { Lektor języka angielskiego, opiekunka w żłobku, wychowawca świetlicy dla } \\
\text { seniorów, stanowisko ds. gospodarowania odpadami }\end{array}$ & 2800 & 7 \\
\hline Konserwator urządzeń elektrycznych & 2919 & 2 \\
\hline $\begin{array}{l}\text { Nauczyciel przedszkola, pracownik fizyczny, robotnik budowlany, elek- } \\
\text { tromonter, brukarz, operator koparki, kierowca samochodu ciężarowego, } \\
\text { pomocniczy robotnik budowlany, pracownik biurowy }\end{array}$ & 3000 & 19 \\
\hline Suszarniowy, pomocnik warstwownicowego & 3100 & 40 \\
\hline Cukiernik, kierowca samochodu dostawczego & 3250 & 4 \\
\hline $\begin{array}{l}\text { Kierowca samochodu ciężarowego kat. C, pomocnik montera, pracownik } \\
\text { myjni, operator maszyn, kierownik działu technicznego, spedytor }\end{array}$ & 3500 & 7 \\
\hline Robotnik budowlany & 3600 & 4 \\
\hline Murarz tynkarz & 3800 & 4 \\
\hline
\end{tabular}




\begin{tabular}{|l|c|c|}
\hline Stanowiska & $\begin{array}{c}\text { Wynagrodzenie } \\
\text { brutto od (w zt) }\end{array}$ & $\begin{array}{c}\text { Liczba } \\
\text { stanowisk } \\
\text { pracy }\end{array}$ \\
\hline Policjant służby prewencyjnej, referent ds. obsługi klientów zagranicznych & 3900 & 11 \\
\hline Szlifierz & 4000 & 8 \\
\hline Monter instalacji sanitarnych & 4210 & 1 \\
\hline Przedstawiciel handlowy & 4500 & 1 \\
\hline Kierowca kat. C & 4700 & 1 \\
\hline Specjalista ds. handlowych & 5000 & 1 \\
\hline
\end{tabular}

Źródło: jak przy tabeli 3.

Mając na względzie ułatwianie kontaktu bezrobotnym i poszukującym pracy z pracodawcami, urząd pracy regularnie organizował giełdy pracy, które umożliwiały szybsze uzyskanie zatrudnienia. Najczęściej giełda pracy organizowana była w siedzibie urzędu i prowadzona przez pośrednika pracy oraz zaproszonego pracodawcę, który przeprowadzał rekrutację kandydatów do pracy.

Tabela 9. Giełdy pracy

\begin{tabular}{|l|c|c|c|c|}
\hline Wyszczególnienie & $\mathbf{2 0 1 7}$ & $\mathbf{2 0 1 8}$ & Różnica & $\begin{array}{c}\text { Różnica } \\
\text { w \% }\end{array}$ \\
\hline Giełdy pracy & 51 & 148 & 97 & 290,20 \\
\hline Uczestniczący bezrobotni & 1044 & 779 & -265 & $-25,38$ \\
\hline Zakwalifikowani do zatrudnienia & 252 & 118 & 134 & $-53,17$ \\
\hline
\end{tabular}

Źródło: jak przy tabeli 3.

Zmniejszenie liczby zarejestrowanych osób bezrobotnych może stanowić wyjaśnienie ograniczonego lub zupełnego braku możliwości skierowania przez urząd pracy osób bezrobotnych do pracy. W tabeli 10 przedstawiono informacje dotyczące wniosków złożonych w PUP przez Wielospecjalistyczny Szpital Wojewódzki w Gorzowie Wielkopolskim o skierowanie osób bezrobotnych na różne stanowiska pracy w ramach prac interwencyjnych.

Tabela 10. Wnioski o skierowanie osób bezrobotnych do pracy złożone przez Wielospecjalistyczny Szpital Wojewódzki (WSW) w Gorzowie Wielkopolskim

\begin{tabular}{|c|c|c|c|c|}
\hline \multirow{2}{*}{$\begin{array}{l}\text { Zlożone } \\
\text { wnioski }\end{array}$} & \multirow[b]{2}{*}{ Nazwa stanowiska } & \multicolumn{2}{|c|}{ Liczba osób } & \multirow{2}{*}{$\begin{array}{c}\text { Realizacja wniosku } \\
\text { - zatrudnienie osób } \\
\text { bezrobotnych }\end{array}$} \\
\hline & & $\begin{array}{l}\text { wnioskowanych } \\
\text { na stanowisko }\end{array}$ & $\begin{array}{l}\text { na stanowisko we- } \\
\text { dług zgody PUP }\end{array}$ & \\
\hline \multicolumn{5}{|c|}{2015} \\
\hline 1 & technik elektroradiologii & 1 & 1 & zrealizowany \\
\hline 1 & pracownik biurowy & 5 & 3 & $\begin{array}{l}\text { zrealizowany (zatrudniono } \\
1 \text { osobę) }\end{array}$ \\
\hline 1 & sekretarka medyczna & 3 & 2 & zrealizowany \\
\hline 1 & salowa & 1 & - & $\begin{array}{l}\text { osoba wskazana we wniosku } \\
\text { zrezygnowała z zatrudnienia }\end{array}$ \\
\hline 1 & pracownik biurowy & 1 & 1 & zrealizowany \\
\hline 1 & salowa & 5 & 5 & zrealizowany \\
\hline 1 & referent ds. kadr & 1 & 1 & zrealizowany \\
\hline 1 & pracownik administracji & 1 & 1 & zrealizowany \\
\hline 1 & sekretarka medyczna & 1 & 1 & zrealizowany \\
\hline 1 & sekretarka medyczna & 1 & 1 & zrealizowany \\
\hline 1 & robotnik gospodarczy & 2 & 2 & zrealizowany \\
\hline 1 & pomoc kuchenna & 1 & 1 & zrealizowany \\
\hline
\end{tabular}




\begin{tabular}{|c|c|c|c|c|}
\hline \multirow{2}{*}{$\begin{array}{l}\text { Złożone } \\
\text { wnioski }\end{array}$} & \multirow[b]{2}{*}{ Nazwa stanowiska } & \multicolumn{2}{|c|}{ Liczba osób } & \multirow{2}{*}{$\begin{array}{c}\text { Realizacja wniosku } \\
\text { - zatrudnienie osób } \\
\text { bezrobotnych }\end{array}$} \\
\hline & & $\begin{array}{l}\text { wnioskowanych } \\
\text { na stanowisko }\end{array}$ & $\begin{array}{l}\text { na stanowisko we- } \\
\text { dług zgody PUP }\end{array}$ & \\
\hline \multicolumn{5}{|l|}{ razem: } \\
\hline 7 & 8 & 23 & 19 & 17 \\
\hline \multicolumn{5}{|c|}{2018} \\
\hline 1 & pomoc kuchenna & 3 & 1 & zrealizowany \\
\hline 1 & salowa & 5 & 5 & niezrealizowany \\
\hline 1 & robotnik gospodarczy & 1 & 1 & zrealizowany \\
\hline 1 & salowa & 4 & 4 & niezrealizowany \\
\hline 1 & pracownik administracyjny & 1 & 1 & zrealizowany \\
\hline 1 & referent ds. ciepłowniczych & 1 & - & $\begin{array}{l}\text { wniosek wycofano ze } \\
\text { względu na brak chętnych } \\
\text { do zatrudnienia }\end{array}$ \\
\hline 1 & operator & 1 & - & \\
\hline 1 & salowa & 2 & - & \\
\hline 1 & robotnik gospodarczy & 1 & - & \\
\hline 1 & pracownik administracji & 1 & - & \\
\hline 1 & specjalista ds. technicznych & 1 & - & \\
\hline 1 & pomoc kuchenna & 2 & - & \\
\hline \multicolumn{5}{|l|}{ razem: } \\
\hline 6 & 7 & 23 & 12 & 3 \\
\hline
\end{tabular}

Źródło: opracowanie własne na podstawie danych z WSW w Gorzowie Wielkopolskim.

Jednym z powodów ograniczonego zainteresowania ofertami pracy na niektórych stanowiskach pracy w szpitalu (np. salowa, robotnik gospodarczy) jest specyfika pracy w podmiocie leczniczym, a konkretnie sprzątanie oddziałów szpitalnych czy pomieszczeń bloku operacyjnego. Nie każdy jest w stanie wykonywać tego rodzaju czynności w warunkach szpitalnych. Poza blokadami natury psychicznej osoby bezrobotne nie podejmują pracy z uwagi na brak dojazdu z miejsca zamieszkania, brak wymaganych kwalifikacji, wychowywanie małoletnich dzieci lub stan zdrowia, który nie pozwala na wykonywanie określonego rodzaju obowiązków.

Niektóre z osób bezrobotnych, po przedstawieniu im oferty pracy, dostarczają do urzędu pracy zwolnienie lekarskie, gdyż w ogólne nie są zainteresowane podjęciem jakiegokolwiek zatrudnienia. Poza powyższym obecnie na rynku pracy obserwuje się wysoką dynamikę przepływów siły roboczej z tradycyjnych sektorów, działów i gałęzi gospodarki do sektorów nowoczesnych i konkurencyjnych, które proponują bardziej atrakcyjne warunki zatrudnienia.

Dodatkowo zmniejszyła się liczba zarejestrowanych osób bezrobotnych, co spowodowane zostało m.in.:

- korzystaniem przez osoby bezrobotne z możliwości przekwalifikowania oraz uzupełnienia kwalifikacji dzięki środkom finansowym z Krajowego Funduszu Szkoleniowego przyznawanym przez urząd pracy,

- poszukiwaniem pracy na własną rękę,

- obniżeniem wieku emerytalnego,

- migracją za pracą,

- korzystaniem z różnego rodzaju wsparcia finansowego, co doprowadziło do rezygnacji z ofert pracy, aby nie utracić środków finansowych w ramach tej pomocy.

Należałoby się zastanowić nad wprowadzeniem rozwiązań systemowych, które pozwoliłyby pracownikom powiatowych urzędów pracy na podejmowanie działań wobec osób bezrobotnych uchylających się od zatrudnienia. Dobrym rozwiązaniem wydaje się również dofinansowanie przez państwo do wynagrodzeń zatrudnianych osób bezrobotnych, które mogłoby poprawić atrakcyjność ofert niskopłatnej pracy.

Powiatowy Urząd Pracy w Gorzowie Wielkopolskim wydaje zezwolenia na pracę sezonową cudzoziemców oraz rejestruje oświadczenia o powierzeniu pracy cudzoziemcom będącym obywatelami: Armenii, Białorusi, Gruzji, Mołdawii, Rosji oraz Ukrainy. Jest to nowe zadanie. Urząd wydaje również informację na 
temat zapewnienia potrzeb kadrowych podmiotu ubiegającego się o zatrudnienie cudzoziemca, która jest niezbędna przy ubieganiu się o wydanie przez wojewodę zezwolenia na pracę. Zezwolenia oraz informacje są wydawane na wnioski składane przez pracodawców. W 2018 r. w PUP w Gorzowie Wielkopolskim przyjął 806 wniosków o wydanie zezwolenia na prace sezonowe.

Tabela 11. Wybrane dokumenty wydane w celu zatrudnienia cudzoziemców

\begin{tabular}{|l|c|c|c|c|}
\hline Rodzaj dokumentu & $\mathbf{2 0 1 7}$ & $\mathbf{2 0 1 8}$ & Różnica & $\begin{array}{c}\text { Różnica } \\
\text { w \% }\end{array}$ \\
\hline Oświadczenie o powierzeniu pracy cudzoziemcom & 17788 & 25439 & 7651 & 43,00 \\
\hline $\begin{array}{l}\text { Informacja starosty o braku możliwości zapewnienia po- } \\
\text { trzeb kadrowych podmiotu powierzającego pracę }\end{array}$ & 502 & 411 & 91 & $-18,13$ \\
\hline
\end{tabular}

Źródło: jak przy tabeli 3.

Liczba wydawanych dokumentów w celu zatrudnienia cudzoziemców ma tendencję wzrostową. W $2018 \mathrm{r}$. zwiększyła się w stosunku do 2017 r. o 43,00\%.

$\mathrm{Na}$ rynku pracy spadła podaż pracowników. Zatrudnianie cudzoziemców w obecnej sytuacji na rynku pracy jest więc niezwykle istotne i umożliwia obsadzenie chociaż części wolnych miejsc pracy. Problemem w przypadku zatrudniania obywateli wymienionych wyżej krajów jest konieczność odnawiania wizy, po którą zmuszeni są wyjechać do miejsca zarejestrowania. Rozwiązaniem w tej sytuacji jest uzyskanie zgody na pobyt stały lub czasowy albo - w szczególnych sytuacjach - uzyskanie karty Polaka. Takie rozwiązanie leży również w interesie pracodawców, gdyż powszechnie wiadomo, że częsta fluktuacja zatrudnionych pracowników zwiększa koszty zatrudnienia.

\section{Zakończenie}

Praca jest zjawiskiem, które uwidacznia się w różnych kontekstach społeczeństwa jako organizmu i systemu. Jest jednak także czymś, co oddziałuje ściśle immanentnie i wpisuje się w strukturę osobowościową człowieka. Stanowi również komponent różnorodnych aksjologii, które Roch Sulima definiuje jako „sformułowane”, gdyż - jego zdaniem - wyraża się w wielorakich koncepcjach filozoficznych, moralnych, religijnych, ideologicznych czy też w samowiedzy obyczajowej (Sulima 2015: 121). Badania społeczne oraz analizy wychodzące poza czystą diagnozę empiryczną pozwalają na stwierdzenie, że praca i jej brak są czynnikiem uruchamiającym inne, szersze zjawiska, która mają swoje reperkusje w życiu jednostek i w funkcjonowaniu społeczeństwa. Choć zjawisko samo w sobie wydaje się dobrze znane i ma bogatą percepcję naukową, badawczą, za każdym razem odsłania swoje odmienne oblicza. Jest tak szczególnie wtedy, gdy uwzględnia się jego konkretną lokalizację oraz przemiany społeczno-gospodarcze, które charakteryzują się określoną dynamiką. Jest to kolejny dowód na to, że społeczeństwo i jednostki odsłaniają swoją dynamiczną i plastyczną strukturę. Powraca klasyczna obserwacja poczyniona przez Georga Simmla, który w różnorodności i wielości form społecznych dostrzega przysługujące im istnienie „własnego życia” (1975: 33-34). 


\section{Bibliografia}

Beksiak J. (2001), Ekonomia. Warszawa: Wydawnictwo Naukowe PWN.

Buchwald A. (2009), Efektywność aktywnych programów rynku pracy w Polsce. Ujęcie regionalne (rozprawa doktorska). Poznań: Uniwersytet Ekonomiczny.

Kwiatkowska G.E. (red.) (2011), Cztowiek w środowisku pracy. Lublin: Wydawnictwo Uniwersytetu Marii Curie-Skłodowskiej.

Milewski R. (red.) (1997), Elementarne zagadnienia ekonomii. Warszawa: Państwowe Wydawnictwo Naukowe. Milewski R. (1999), Podstawy ekonomii. Warszawa: Wydawnictwo Naukowe PWN.

Giermanowska E. (2013), Ryzyko elastyczności czy elastyczność ryzyka. Instytucjonalna analiza kontraktów zatrudnienia. Warszawa: Wydawnictwo Uniwersytetu Warszawskiego.

Kozek W. (red.) (2003), Instytucjonalizacja stosunków pracy w Polsce. Warszawa: Scholar.

Jarmołowicz W., Woźniak B. (2006), Polityka państwa wobec bezrobocia. „Zeszyty Naukowe. Polskie Towarzystwo Ekonomiczne", 4, s. 113-130.

Kobiałka G. (2012), Doradztwo zawodowe. Warszawa: Fundacja Inicjatyw Społeczno-Ekonomicznych.

Próchnicki L. (2008), Makroekonomia. Szczecin: Zachodniopomorska Szkoła Biznesu.

Przybyszewski R. (2007), Kapitat ludzki w procesie ksztattowania gospodarki opartej na wiedzy. Warszawa: Difin.

Romer D. (2000), Makroekonomia dla zaawansowanych. Warszawa: Wydawnictwo Naukowe PWN.

Simmel G. (1975), Socjologia, (tłum. M. Łukasiewicz). Warszawa: Państwowe Wydawnictwo Naukowe.

Simmel G. (2008), Podziat pracy jako przyczyna rozejścia się kultury subiektywnej i kultury obiektywnej [w:] tegoż, Pisma socjologiczne (tłum. M. Łukasiewicz). Warszawa: Oficyna Naukowa.

Skrzypiński D. (2001), Organizacje pracodawców i przedsiębiorców w procesie ksztattowania się stosunków przemystowych w Polsce po 1989 roku. Toruń: Wydawnictwo Adam Marszałek.

Sulima R. (2015), Pracowitość [w:] M. Bogunia- Borowska (red.), Fundamenty dobrego spoteczeństwa. Wartości. Kraków: Wydawnictwo Znak.

Szaban J.M. (2013), Rynek pracy w Polsce i Unii Europejskiej. Warszawa: Difin.

Whitehead G. (2001), Ekonomia (tłum. A. Unterschuetz). Poznań: Zysk i S-ka.

Woźniak M. G. (2013), Gospodarka Polski 1990-2011, t. 3, Droga do spójności spoteczno-ekonomicznej. Warszawa: Wydawnictwo Naukowe PWN. 